DOI:http://dx.doi.org/10.24093/awejtls/vol1no2.12

\title{
Morpho-Syntactic Complexity in the Translation of the Seven Suspended Odes
}

\author{
Eyhab Abdulrazak Bader Eddin \\ English Department \\ Faculty of Languages and Translation, \\ King Khalid University, Saudi Arabia
}

\begin{abstract}
This paper attempts at bringing a new degree of precision into the analysis of the translation problems encountered in Arberry's Translation of the Seven Suspended Odes, i.e. morphosyntactic complexity. Because the pair of languages under investigation is genetically and thus typologically different, it calls into question how to tackle complexity in morphology and syntax in translation. The paper brings into focus Arabic inflections which indicate 'emphasis, duality and gender', and how they may be properly approached. Additionally, the syntactic constituents of Cognate Accusative Object, Causative Object, Accusative of State and Substitute are examined in Arabic and how they can be overcome in translation. Evidence from the Holy Quran has been adduced for illustration and elucidation purposes as necessity demands. Last but not least, pleonasm and paronomasia have been linguistically pulled apart, to be followed by an approach to grappling with such phenomena in translation. Some strategies have been referred to, or devised in cases of the above constituents and the like.
\end{abstract}

Keywords: Al-Muallaqat, Arberry's Translation, inflections, morpho-syntactic complexity, pleonasm

Cite as: Bader Eddin, E. A. (2017). Morpho-Syntactic Complexity in the Translation of the Seven Suspended Odes. Arab World English Journal for Translation \& Literary Studies, 1(2).

DOI:http://dx.doi.org/10.24093/awejtls/vol1no2.12 